\title{
Effect of Flotation Time and Collector Dosage on Estonian Phosphorite Beneficiation
}

\author{
Kadriann Tamm ${ }^{1,2, *}$, Zeinab Arab Zadeh ${ }^{1, *}$, Rein Kuusik ${ }^{1}$, Juha Kallas ${ }^{1}$, Jason Yang ${ }^{3}$, Kaia Tõnsuaadu ${ }^{1}$ and \\ Andres Trikkel ${ }^{1}$ \\ 1 Laboratory of Inorganic Materials, Tallinn University of Technology, 12616 Tallinn, Estonia; \\ rein.kuusik@ttu.ee (R.K.); juha.kallas@ttu.ee (J.K.); kaia.tonsuaadu@taltech.ee (K.T.); \\ Andres.trikkel@ttu.ee (A.T.) \\ 2 Department of Geological Resources, Geological Survey of Estonia, 10115 Rakvere, Estonia \\ 3 GTK Mintec, FI-02151 Espoo, Finland; jason.yang@gtk.fi \\ * Correspondence: kadriann.tamm@taltech.ee (K.T.); hoda.abzh@gmail.com (Z.A.Z.)
}

\section{check for}

updates

Citation: Tamm, K.; Arab Zadeh, Z.; Kuusik, R.; Kallas, J.; Yang, J.;

Tõnsuaadu, K.; Trikkel, A. Effect of Flotation Time and Collector Dosage on Estonian Phosphorite Beneficiation. Minerals 2021, 11, 114. https:// doi.org/10.3390/min11020114

Received: 10 December 2020

Accepted: 18 January 2021

Published: 24 January 2021

Publisher's Note: MDPI stays neutral with regard to jurisdictional claims in published maps and institutional affiliations.

Copyright: (c) 2021 by the authors. Licensee MDPI, Basel, Switzerland. This article is an open access article distributed under the terms and conditions of the Creative Commons Attribution (CC BY) license (https:/ / creativecommons.org/licenses/by/ $4.0 /)$.

\begin{abstract}
Phosphorus is an essential and non-substitutable element for the cellular processes of all living organisms. The main source of phosphorus in the biosphere is phosphate rock. With more than $700 \mathrm{Mt}$ phosphate rock, Estonia holds the largest sedimentary phosphate rock deposits in the European Union. Estonian phosphate rock is particularly outstanding due to its remarkably low content of hazardous heavy metals such as Cadmium $(<5 \mathrm{ppm})$ and trace elements of Uranium $(<50 \mathrm{ppm})$. It is also a reliable source of valuable elements such as rear earth elements (REEs). The aim of this study was to investigate the distribution of the main minerals (apatite and quartz) between slimes, tailings, and concentrates that formed at the froth flotation of Estonian phosphate rock with the up-to-date level of know-how and techniques. Subsequently, the relationship between the obtained grades and recovery levels in concentrates was determined based on the collector dosage and flotation duration. It was observed that the fine fraction of the tailings contains 17.9-33.49 wt $\%$ $\mathrm{P}_{2} \mathrm{O}_{5}$ that can be added to the final product. Moreover, it was found that, with the lower dosage of the collector, the extended flotation time does not influence the phosphate grade and a high amount of quartz remains in the concentrates. It was also shown that, by raising the collector dosage and setting the flotation time, an adequate grade ( $>32 \mathrm{wt} \% \mathrm{P}_{2} \mathrm{O}_{5}$ ) and recovery (up to $98 \%$ ) can be gained. The results showed that Estonian phosphate rock can be beneficiated to produce a high-quality concentrate at high recovery levels by modifying the main flotation parameters depending on the properties of the ore.
\end{abstract}

Keywords: Estonian phosphorite; beneficiation; reverse flotation; phosphate concentrates; phosphate recovery

\section{Introduction}

Estonian phosphate rock is a fine- or coarse-grained, slightly bioclastic quartz sandstone. The SEM and EDX observation on lingulate brachiopod shells show precipitation of secondary apatite in a form of fluorapatite or carbonate fluorapatite and other minerals (especially pyrite) after microbial decay of the organic matter in shells [1].

This typical shelly phosphorite occurs at the Upper Cambrian/Lower Ordovician boundary (Kallavere Formation) [2]. The basic rock-forming minerals are quartz and biogenic phosphate (Francolite apatite: $\left.\mathrm{Ca}_{10-x-y} \mathrm{Na}_{x} \mathrm{Mg}_{\mathrm{y}}\left(\mathrm{PO}_{4}\right)_{6-z}\left(\mathrm{CO}_{3}\right)_{z} \mathrm{~F}_{0.4 z} \mathrm{~F}\right)$ which originate from remnants of brachiopods in association of calcite $\left(\mathrm{CaCO}_{3}\right)$, gypsum $(\mathrm{CaSO}$. $\left.2 \mathrm{H}_{2} \mathrm{O}\right)$, potassium feldspar $\left(\mathrm{KAlSi}_{3} \mathrm{O}_{8}\right)$, glauconite $\left((\mathrm{K}, \mathrm{Na})\left(\mathrm{Fe}^{3+}, \mathrm{Al}, \mathrm{Mg}\right)_{2}(\mathrm{Si}, \mathrm{Al})_{4} \mathrm{O}_{10}(\mathrm{OH})_{2}\right)$, and ferrous hydroxides $\left(\mathrm{Fe}(\mathrm{OH})_{2}\right)$, which occur in insignificant amounts. To a lesser extent, Estonian phosphorite also contains pyrite $\left(\mathrm{FeS}_{2}\right)$ and dolomite $\left(\mathrm{CaMgCO}_{3}\right)$ [3]. These matrix sandstones often show a well-developed, small scale, and randomly oriented cross bedding with individual bed sets about $20-30 \mathrm{~cm}$ thickness [4]. The proportion of these 
minerals varies with layers and deposits. The content of the remnants of brachiopods in the rock ranges from $5-10 \%$ to $80-90 \%$ which can be seen in broken pieces or intact shells with a thickness from a few millimeters to $1 \mathrm{~cm}$ size [5].

In Estonia, phosphate rock deposits are divided into four sources:

1. Nodular Phosphorite: The $\mathrm{P}_{2} \mathrm{O}_{5}$ content does not exceed $20 \mathrm{wt} \%$.

2. In the form of finely divided phosphorous granules, consisting either detritus or autogenous micro spherites of the original chemicals.

3. Brachiopods detritus (Obolus and Lingula families). Phosphate is represented herein as francolite apatite with 2.6-3.3 $\mathrm{wt} \%$ of $\mathrm{P}_{2} \mathrm{O}_{5}$.

4. Knight fish as fossils. The bone fragments of phosphorous fish found in the Devonian strata contains up to $36 \mathrm{wt} \% \mathrm{P}_{2} \mathrm{O}_{5}$ [6].

The available data indicate that the main phosphorus-bearing layers are sand and shellfish, which contain $9-13 \mathrm{wt} \% \mathrm{P}_{2} \mathrm{O}_{5}, 13-18 \mathrm{wt} \% \mathrm{CaO}, 55-62 \mathrm{wt} \% \mathrm{SiO}_{2}, 1-2 \mathrm{wt} \%$ pyrite $\left(\mathrm{FeS}_{2}\right), 1-2 \mathrm{wt} \%$ iron oxides, $1.3-1.7 \mathrm{wt} \% \mathrm{CO}_{2}, 0.36-1.01 \mathrm{wt} \% \mathrm{~F}, 20-28 \mathrm{ppm}$ Uranium, and about $0.2 \mathrm{wt} \%$ organic carbon [7].

The shell contains between $33.67-35.45 \%$ and $46.16-51.5 \%$ of $\mathrm{P}_{2} \mathrm{O}_{5}$ and $\mathrm{CaO}$, respectively. At the same time, the $\mathrm{CO}_{2}$ content increases to $2.22-4.70 \%$ and the silicon content decreases to $0.50-2.0 \%$ [8].

Cadmium $(\mathrm{Cd})$ is one of the trace elements highly enriched in phosphate rocks. The characteristics of PRs regarding the Cd content exhibit the potential pollutant of the produced fertilizer that will be transferred to the soil and food chain. Sedimentary phosphate rocks that were under the investigation from various locations in the world show that generally the content of the $\mathrm{Cd}$ is between $3-150 \mathrm{mg} / \mathrm{kg}$. While igneous deposits are typically less in Cd content [9].

One of the most important advantages of Estonian phosphate rock is its remarkable low content of $\mathrm{Cd}$ which is up to $5 \mathrm{mg} / \mathrm{kg}$. The Cd content in phosphate rocks in the United States, Morocco, Russia, and China (Yunam deposit) is up to 185, 165, 13, and 4 respectively [10]. The $\mathrm{Cd}$ concentration is reduced by use of sulfide salt which results in the precipitation of $\mathrm{Cd}$ following by the separation of the solid phase in filtration stage [11]. $\mathrm{Cd}$ concentration plays a vital role in determining the quality of phosphate resources which does not have any critical limit, because the maximum allowable concentration depends largely on soil characteristics, water quality, crop type, etc. [10]. However, European countries implemented a threshold of $10 \mathrm{mg} / \mathrm{kg}$ of cadmium concentration on phosphate rock imports [5,11].

Uranium is one of the strategic elements in phosphate rock. Israel, Morocco, and Egypt deposits contain 120, 97, and $90 \mathrm{mg} / \mathrm{kg}$ of U. The content of the U in Estonian phosphate rock is up to $50 \mathrm{mg} / \mathrm{kg}$ which can be a source of nuclear energy in the European Union [12].

The geological exploration of the Estonian shelly phosphorite initiated in 1919, by opening an underground mine at Ülgase which is located in the northern part of the Maardu phosphorite deposit. However, the mine was shut down in 1938 due to a fire in the mine main building. The opencast mine practices in Maardu resulted in an environmental hazard owing to the self-ignition of graptolite argillite in dump piles. The exploitation of the phosphorite continued for more than 80 years in an environmentally hazardous way resulting in the destroyed large area as well as exhaustion of the mineable phosphorite. Therefore, the Maardu deposit mining and beneficiation industry was terminated and excluded from the list of active reserves in the late 1990s [5].

Despite all the potential advantages, e.g., economic, political, and technological, Estonian phosphate rock deposits are not currently exploited due to environmental concerns as well as ecological impacts as it is destructive in nature and damages to the inhabited and agricultural lands.

Currently, the beneficiation process along with wet process for Estonian phosphate rock is mainly conducted in laboratory scale (1978-1985). Considering a gap of at least 30 years, research in this field needs to recommence to re-assess the economic, technological, 
and environmental challenges for processing Estonian phosphorite. In 2018, with the governmental support for further scoping studies, innovative thermal process has been evaluated to produce high-grade phosphoric acid. Among the technological challenges, preliminary beneficiation from low level $(5-20 \%)$ to the marketable grade $(28-32 \%)$ is the critical one. Reverse flotation was found to be the most efficient processes to upgrade the phosphate level in Estonian phosphorite which is applied in this study.

Phosphate concentration that is needed in wet process should contain more than $30 \% \mathrm{P}_{2} \mathrm{O}_{5}$, less than $1 \% \mathrm{MgO}$, and $1.6 \mathrm{CaO} / \mathrm{P}_{2} \mathrm{O}_{5}$ ratio and between $2-3 \%$ of $\mathrm{Al}_{2} \mathrm{O}_{3}$ and $\mathrm{Fe}_{2} \mathrm{O}_{3}[3]$.

To upgrade the phosphate grade different beneficiation methods are applied currently, with the froth flotation being the most efficient and industrially used [3]. This method is based on the hydrophobicity of the particles to ascending air bubbles that float a particlerich effervescence (froth) on the flowing suspension surface over the edge of the flotation cell. The efficiency of the separation process is determined by the selective hydrophobization of the hydrophilic minerals in apatite, calcium fluoride, calcite, and dolomite with reagents [13]. Studies have shown that the most beneficial reagent to remove the above mentioned minerals, particularly quartz is cation amine collectors in reverse flotation process that delivers a high concentration (around 30\%) of siliceous phosphate. However, the amount of reactive silicon should be considered for the production of phosphoric acid in order to replace $\mathrm{SiF}_{4}$ and fluorosilicates and prevent the formation of corrosive hydrofluoric acid $[3,14]$.

The efficiency of the flotation method as a dynamic system varies by changing any of the involving parameters [3]. Mineralogical properties [15-17], flotation reagents [18-21], and flotation medium characteristics [22-24] as technical and chemical components have been under investigations in many studies. However, effects of the flotation time and collector dosage have been overlooked in researches and studies.

This study investigates the experimental and functional information by studying the mineral characteristics of the Ülgase deposit-northern Estonia phosphate rock and its performance in the reverse flotation process while changing the flotation time and collector dosage. The flotation experiments were conducted in GTK Mintec Laboratory in Finland and chemical characterization and data analysis were done at Tallinn University of Technology, Estonia. The focus is on the chemical characteristics of slimes, tailings, and concentrates. Subsequently, recovery and grade was calculated and the particle size analysis were conducted to find an optimum flotation process for Estonian phosphate rock enrichment. These data can be used for further studies and the simulation and modelling of the beneficiation of Estonian phosphate rock. To achieve the above-mentioned aims, four main objectives were examined:

1. Investigating the effect of flotation rate and collector's dosage in liberation of the main minerals (quartz and apatite) in the flotation process of phosphorite from Ülgase deposit in 10 different tests.

2. Screening of the tailings and concentrates into three distinct fractions followed by particle size distribution measurement.

3. Analysis of the samples by XRF, chemical analysis, and XRD.

4. Data processing and visualization that can be utilized to identify the suitable and optimized condition of the Estonian phosphate rock enrichment.

\section{Materials and Methods}

\subsection{Raw Material Characterization}

The First phase of the study was to characterize the phosphate rock which was collected from an old mine in Ülgase by the Geological Institute at Tallinn University of Technology (sampling was part of the project RITA1/01-01-11). The samples were preprocessed and the chemical analysis showed a total of $24.28 \% \mathrm{P}_{2} \mathrm{O}_{5}, 32.73 \% \mathrm{SiO}_{2}, 1.36 \% \mathrm{Fe}_{2} \mathrm{O}_{3}$, $0.23 \% \mathrm{MgO}$, and $32.42 \% \mathrm{CaO}$. The most efficient collector for flotation technology was 
identified by benchmarking at the Outokumpu GTK Mintec Research Center of the Finnish Geological Survey. The overall flow of the research study is shown in Figure 1 as Phase 1.

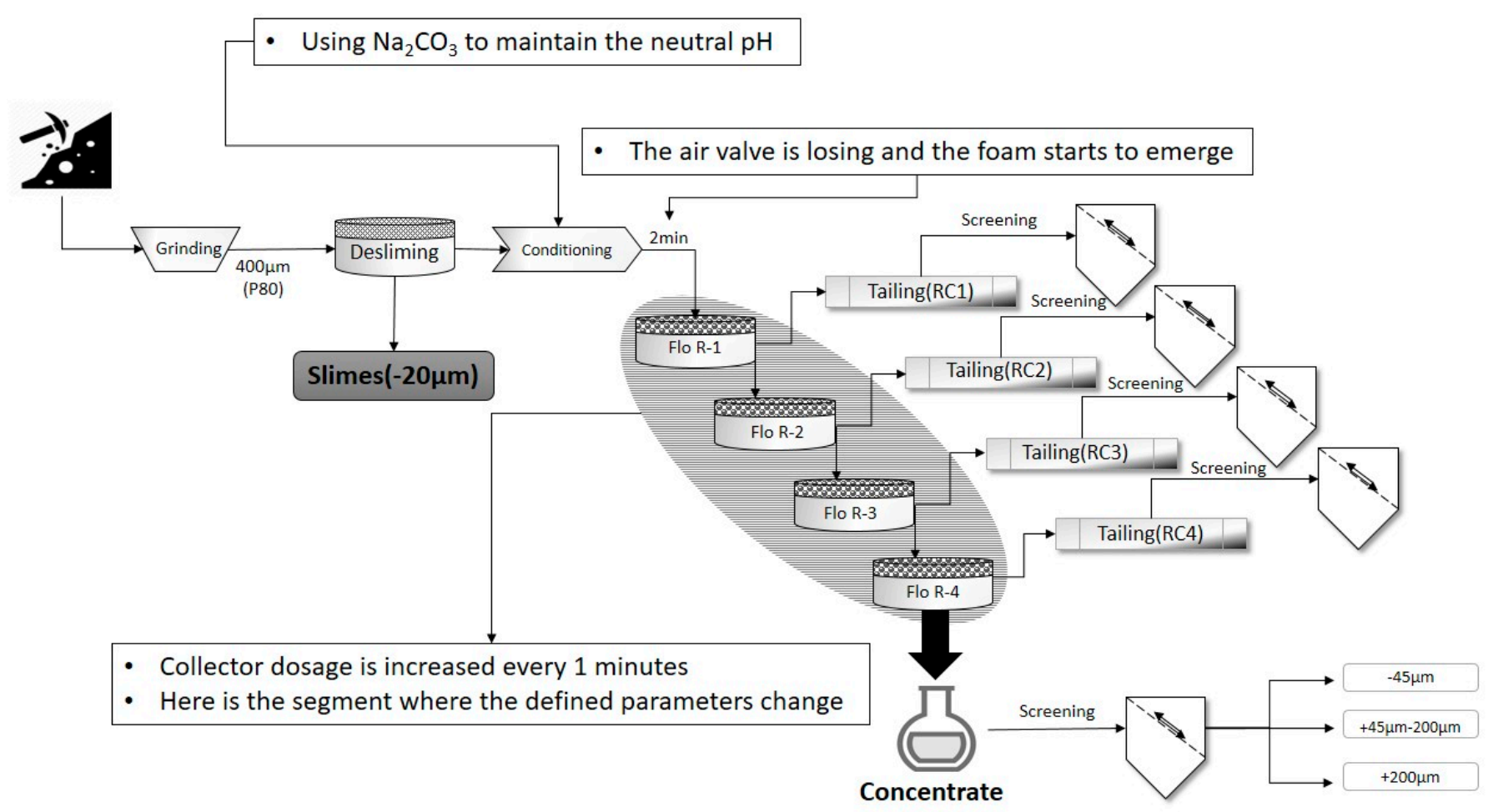

Figure 1. Experimental Design to study the Estonian phosphate rock optimum flotation process (Phase 1).

\subsection{Flotation Test}

This study is designed based on changing the collector dosage and collecting time and observing the influence of each parameter while keeping other parameter stable. Therefore, 10 different flotation tests were conducted. The flotation time was from 6 to $14 \mathrm{~min}$, and the cation amine collector was Custamine 1205 (developed by ArrMaz as a part of Arkema, FL, USA) [25] which was added to the flotation cell from 400 to $800 \mathrm{~g} / \mathrm{t}$ [25]. The flotation tests were done in a LabCell (Four Marks, United Kingdom) flotation equipment with the cell volume of $1.5 \mathrm{~L}$. The changes in the time and collector dosage were in $4 \mathrm{~min}$ and $200 \mathrm{~g} / \mathrm{t}$ increments, respectively. Thus, three dosages of collectors were used as minimum $(400 \mathrm{~g} / \mathrm{t})$, optimum $(600 \mathrm{~g} / \mathrm{t})$, and maximum $(800 \mathrm{~g} / \mathrm{t})$; with each collector dosage three tests with different flotation time were conducted, firstly in $6 \mathrm{~min}$, secondly in $10 \mathrm{~min}$, and thirdly in $14 \mathrm{~min}$ in a total of 9 main tests and test 0 as a preparatory test. Wet grinding, de-sliming, and flotation process was identical in all the tests. The ores were first ground in a rod mill to the size of $400 \mu \mathrm{m}$ (P80 in which $80 \%$ of the particles pass through the screening step). Subsequently, they were de-slimed by the hydrodynamic settling method in order to remove the extra fine particles $(-20 \mu \mathrm{m})$ using tap water at room temperature. The collected samples labeled as Slimes. In the next step $150 \mathrm{~g} / \mathrm{t}$ of Custamine 1205 and $\mathrm{Na}_{2} \mathrm{CO}_{3}$ were added and the situation was kept for $1 \mathrm{~min}$. Then each test was divided into 4 various segments characterized by a distinct flotation time and collector dosage. Thus, Flo R-x (Table 1) indicates the flotation round in each segment of the experiment in which a defined amount of collector dosage is added and tailings are collected after a specific allocated time. In four separate steps, the experiment continued in which 150 to $400 \mathrm{~g} / \mathrm{t}$ of the collector was added in each step and the froth product was collected for 2-4 min with an overall flotation time of 6-14 min resulting in four sub-tailings, Flo R-1 (collecting time 2), Flo R-2 (collecting time 2, 3, and $4 \mathrm{~min}$ ), Flo R-3 (collecting time 1, 3, and $4 \mathrm{~min}$ ), Flo R-4 (1, 2, and $4 \mathrm{~min}$ ) for 400, 600, and $800 \mathrm{~g} / \mathrm{t}$ of collector dosage, respectively. RT as 
concentrate in the final stage was gathered from the cell. The designed experiments of the flotation time and collector dosage are shown in Table 1.

The collected samples from the flotation test were filtered, dried, weighted, bagged, and labeled. Tailings were labeled as RC1, RC2, RC3, and RC4 for Flo R-1, Flo R-2, Flo R-3, and Flo R-4, respectively.

The sample screening preparation for analyses and measurements were performed at the Taltech Inorganic Materials Laboratory, in collaboration with the Taltech Geological Institute (GI) and Geological Survey of Estonia (GSE). The XRF, XRD, chemical analysis, and particle size distribution analysis were conducted. Subsequently, the data were gathered and processed.

\subsection{Products Characterization}

The overall analytical method conducted to characterize the Estonian phosphate rock is shown in Figure 2 as Phase 2.

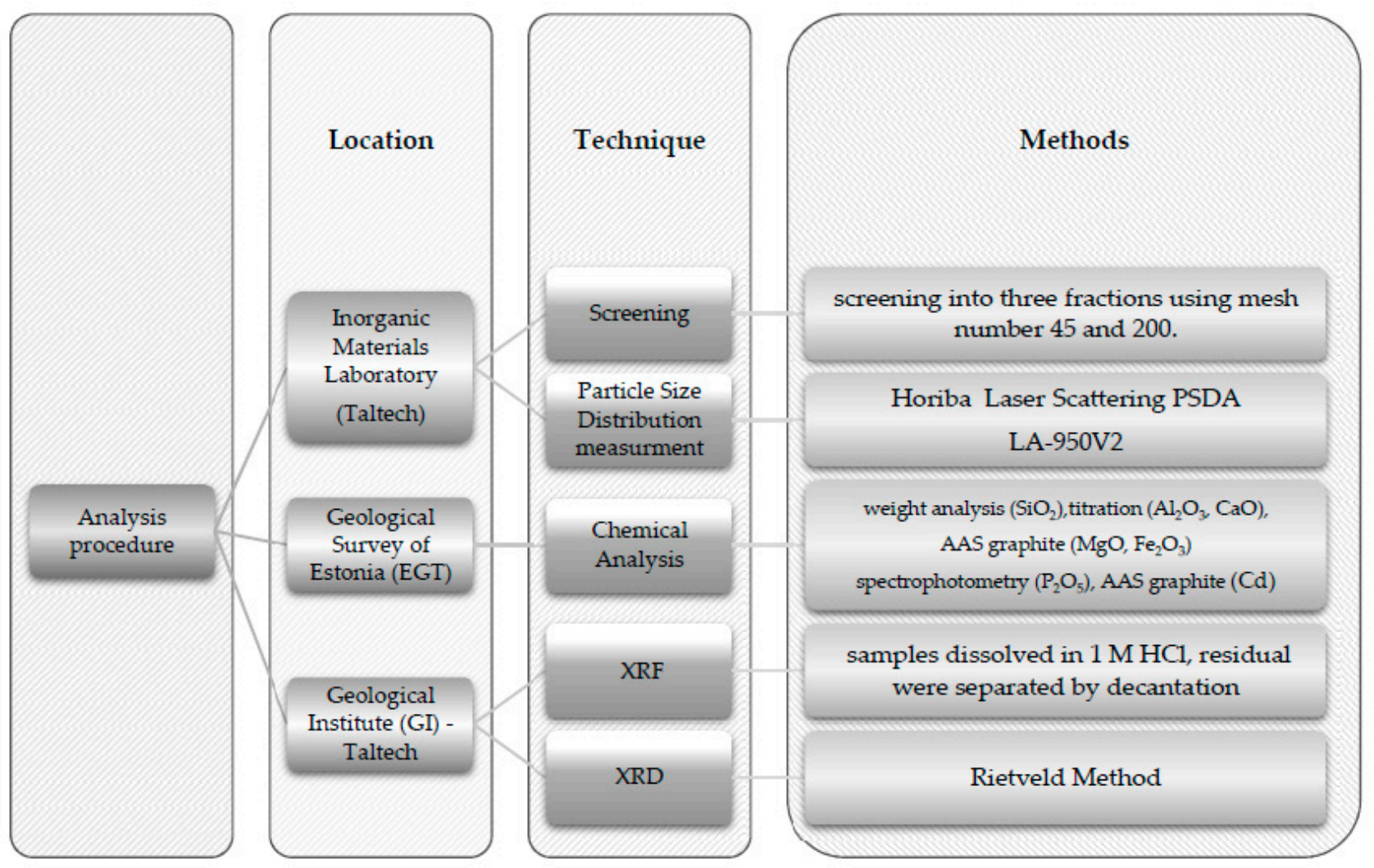

Figure 2. Analysis method of the obtained samples (Phase 2).

Each flotation product was screened into three fractions of $-45 \mu \mathrm{m},+45-200 \mu \mathrm{m}$ and $+200 \mu \mathrm{m}$ by applying $15 \mathrm{~min}$ vibration. The mesh size was 45 and 200. The amount on each mesh was weighted and bagged and the data collected on the corresponding dataset. Consequently, particle size distribution measurement was conducted to obtain the mean size of each fraction using Horiba Laser Scattering Particle Size distribution analyzer LA-950V2 (Kyoto, Japan).

All the sieved samples were analyzed by XRF (X-ray fluorescence analyzer Bruker S-4) in Geological Institute at Tallinn University of Technology using melting method for macro components and powder method for sulfur, fluoride and REEs. XRD was also conducted using Rietveld method using a Bruker D-8 diffractometer. 
Table 1. Estonian phosphate rock beneficiation in 10 distinct tests regarding collector dosage and flotation time.

\begin{tabular}{|c|c|c|c|c|c|c|c|c|c|c|c|}
\hline \multirow{2}{*}{\multicolumn{4}{|c|}{ Variable Flotation Parameters }} & \multicolumn{8}{|c|}{ Flotation } \\
\hline & & & & \multicolumn{2}{|c|}{ FloR-1 } & \multicolumn{2}{|c|}{ FloR-2 } & \multicolumn{2}{|c|}{ FloR-3 } & \multicolumn{2}{|c|}{ FloR-4 } \\
\hline $\begin{array}{c}\text { Test } \\
\mathrm{nr}\end{array}$ & $\begin{array}{l}\text { Collector } \\
\text { dose, } g / t\end{array}$ & $\begin{array}{c}\text { Flotation } \\
\text { time }\end{array}$ & Conditioning & Dosage, $\mathrm{g} / \mathrm{t}$ & Collectingtime & Dosage, $\mathrm{g} / \mathrm{t}$ & Collectingtime & Dosage, $\mathrm{g} / \mathrm{t}$ & Collectingtime & Dosage, $\mathrm{g} / \mathrm{t}$ & Collectingtime \\
\hline 0 & 400 & 4 & $\begin{array}{c}\mathrm{pH} 7 \text { by adding } \\
\mathrm{Na}_{2} \mathrm{CO}_{3} \\
\text { Collector } 400 \mathrm{~g} / \mathrm{t}, \\
1 \mathrm{~min}\end{array}$ & - & - & - & - & - & - & - & -1 \\
\hline 1 & 400 & 6 & & 0 & 2 & 100 & 2 & 100 & 1 & 50 & 1 \\
\hline 2 & 400 & 10 & & 0 & 2 & 100 & 3 & 100 & 3 & 50 & 2 \\
\hline 3 & 400 & 14 & & 0 & 2 & 100 & 4 & 100 & 5 & 50 & 3 \\
\hline 4 & 600 & 6 & pH 7 by adding & 0 & 2 & 200 & 2 & 150 & 1 & 100 & 1 \\
\hline 5 & 600 & 10 & $\mathrm{Na}_{2} \mathrm{CO}_{3}$ & 0 & 2 & 200 & 3 & 150 & 3 & 100 & 2 \\
\hline 6 & 600 & 14 & Collector $150 \mathrm{~g} / \mathrm{t}$, & 0 & 2 & 200 & 4 & 150 & 5 & 100 & 3 \\
\hline 7 & 800 & 6 & $1 \mathrm{~min}$ & 0 & 2 & 300 & 2 & 200 & 1 & 150 & 1 \\
\hline 8 & 800 & 10 & & 0 & 2 & 300 & 3 & 200 & 3 & 150 & 2 \\
\hline 9 & 800 & 14 & & 0 & 2 & 300 & 4 & 200 & 5 & 150 & 3 \\
\hline
\end{tabular}


Chemical analysis was performed according to the Geological Survey of Estonia using the weight analysis method for quartz, titration for $\mathrm{Al}_{2} \mathrm{O}_{3}$ and $\mathrm{CaO}$ content, AAS (Atomic Absorption Spectrometry) flame for $\mathrm{MgO}$ and $\mathrm{Fe}_{2} \mathrm{O}_{3}$ detection, spectrophotometry for $\mathrm{P}_{2} \mathrm{O}_{5}$, and AAS graphite for $\mathrm{Cd}$ content.

Another requirement to evaluate the quality of the beneficiated phosphate rock is the ratio of $\mathrm{CaO} / \mathrm{P}_{2} \mathrm{O}_{5}$ which is recommended to be up to 1.6. This parameter is also calculated to identify the best flotation process for the beneficiation of Estonian phosphate rock.

\section{Results and Discussion}

\subsection{Screening}

Generally, it was observed that in tailings particle size distribution was mainly between 45 and $200 \mu \mathrm{m}$ with the average mean size of $165.5 \mu \mathrm{m}$. As the flotation time increases (Figure 3), the proportion of the coarser particles increases, and more particles remained on the mesh number 200 with the average mean size of $246.97 \mu \mathrm{m}$. This proportion in test 8 and 9 becomes approximately equal with $50 \%$ to $49 \%$ and $51 \%$ to $48 \%$, respectively. Also, the percentage of the fine particles $(-45 \mu \mathrm{m})$ is significantly lower compared to two other groups regardless of the flotation time and collector dosage with the average mean particle size of $27.77 \mu \mathrm{m}$. This phenomenon can be explained by the fact that coarser particles have a higher chance to collide with the bubbles, and are therefore collected as tailings, while finer particles are mainly collected as slimes before the flotation process.

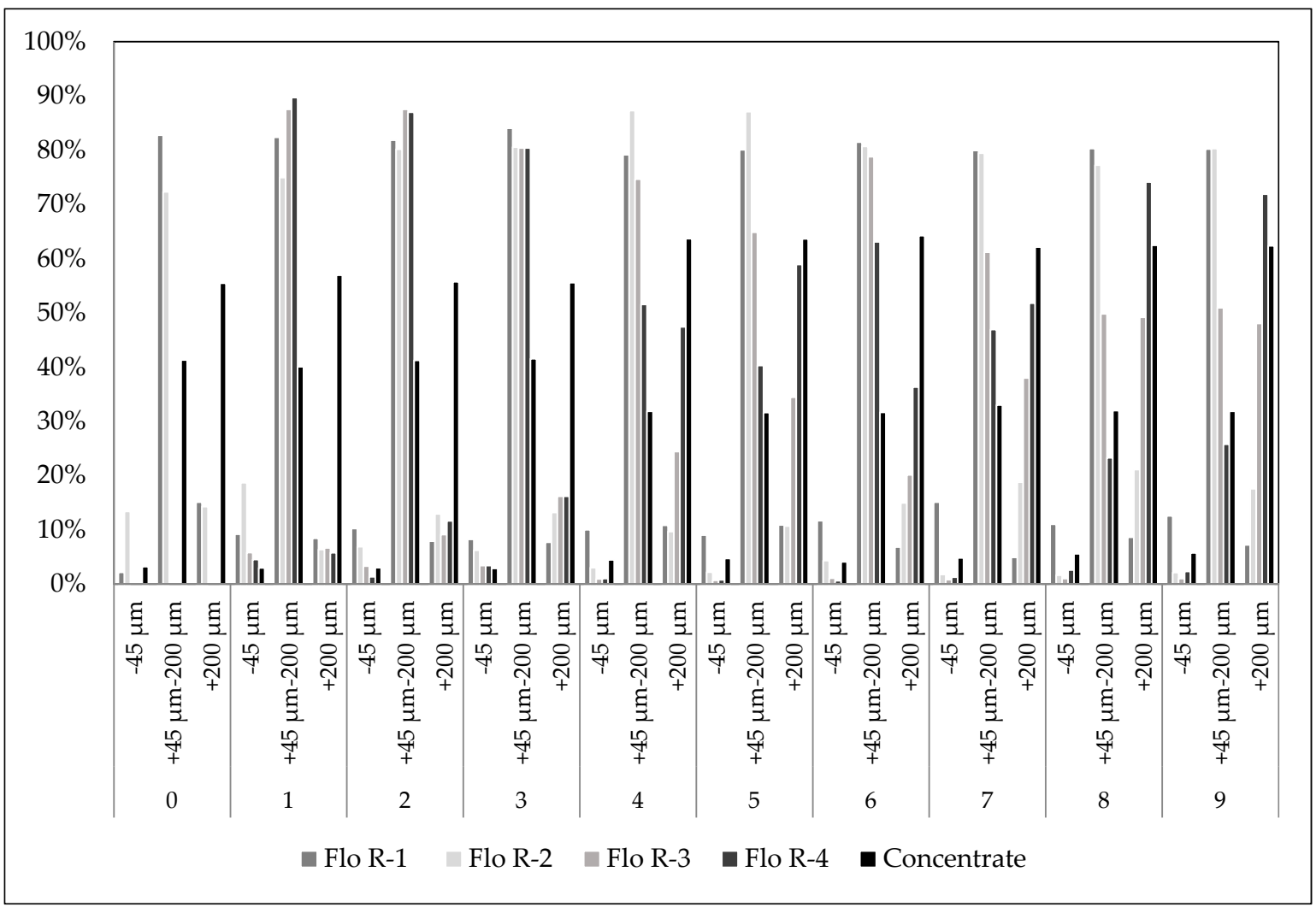

Figure 3. Particle size distribution in three distinct fractions.

In contrast, in concentrates (RT) as it is illustrated in Figure 3 the overall distribution of the particles is in favor of coarse particles $(>200 \mu \mathrm{m})$ with the average mean size of $436.93 \mu \mathrm{m}$ compared to tailings particle size distribution, explaining that an optimum particle size can be calculated for an efficient flotation. The Mean particle size for each fraction can be seen in Table 2 where the Mean particle sizes in the slimes are significantly lower than the fine particle fractions in tailings and concentrates with $11.4 \mu \mathrm{m}$ diameter. 
However, second fractions in tailings and concentrates $(+45-200 \mu \mathrm{m})$ are relatively the same with $166.3 \mu \mathrm{m}$ and $165.6 \mu \mathrm{m}$, respectively. Considering the coarse fraction of the particles $(+200 \mu \mathrm{m})$, the difference between tailings and concentrates is remarkable with the diameter of $250.3 \mu \mathrm{m}$ and $436.0 \mu \mathrm{m}$, orderly which can be concluded that flotation of the heavy particles larger than $250.3 \mu \mathrm{m}$ is unlikely due to two main possible reasons: (i) the apatite-bearing particles weight and (ii) the hydrophilicity of the apatite-bearing particles.

Table 2. Mean Particle size in flotation products.

\begin{tabular}{ccc}
\hline Sample ID & Fraction & Median Particle Size $(\mu \mathrm{m})$ \\
\hline Slimes & $-20 \mu \mathrm{m}$ & 11.4 \\
& $-45 \mu \mathrm{m}$ & 28.0 \\
Tailings & $+45-200 \mu \mathrm{m}$ & 166.3 \\
& $+200 \mu \mathrm{m}$ & 250.3 \\
& $-45 \mu \mathrm{m}$ & 31.0 \\
Concentrates & $+45-200 \mu \mathrm{m}$ & 165.6 \\
& $+200 \mu \mathrm{m}$ & 439.0 \\
\hline
\end{tabular}

\subsection{Chemical Analysis}

Figure 4 illustrates the chemical composition in slimes for tests 0 to 9 named as NT0 to NT9. These products can be added to concentrates to increase the final $\mathrm{P}_{2} \mathrm{O}_{5}$ grade and recovery rate. The phosphate content in the slimes originates from brachiopods detritus which was liberated during the wet grinding. The slimes from tests 3-9 contain the highest amount of phosphorus with almost $35.6 \%$ and slightly more than $10 \% \mathrm{SiO}_{2}$. This step (de-sliming) is critical because it can help to reduce the cost of the flotation process as it avoids using extra reagents. In addition, it can be observed that the $\mathrm{Fe}_{2} \mathrm{O}_{3}$ and $\mathrm{MgO}$ content are relatively similar in all the slimes samples with approximately $3 \mathrm{wt} \%$ for each. This amount of $\mathrm{Fe}_{2} \mathrm{O}_{3}$ and $\mathrm{MgO}$ is before beneficiation and will be reduced in combination with concentrates to the marketable requirements.

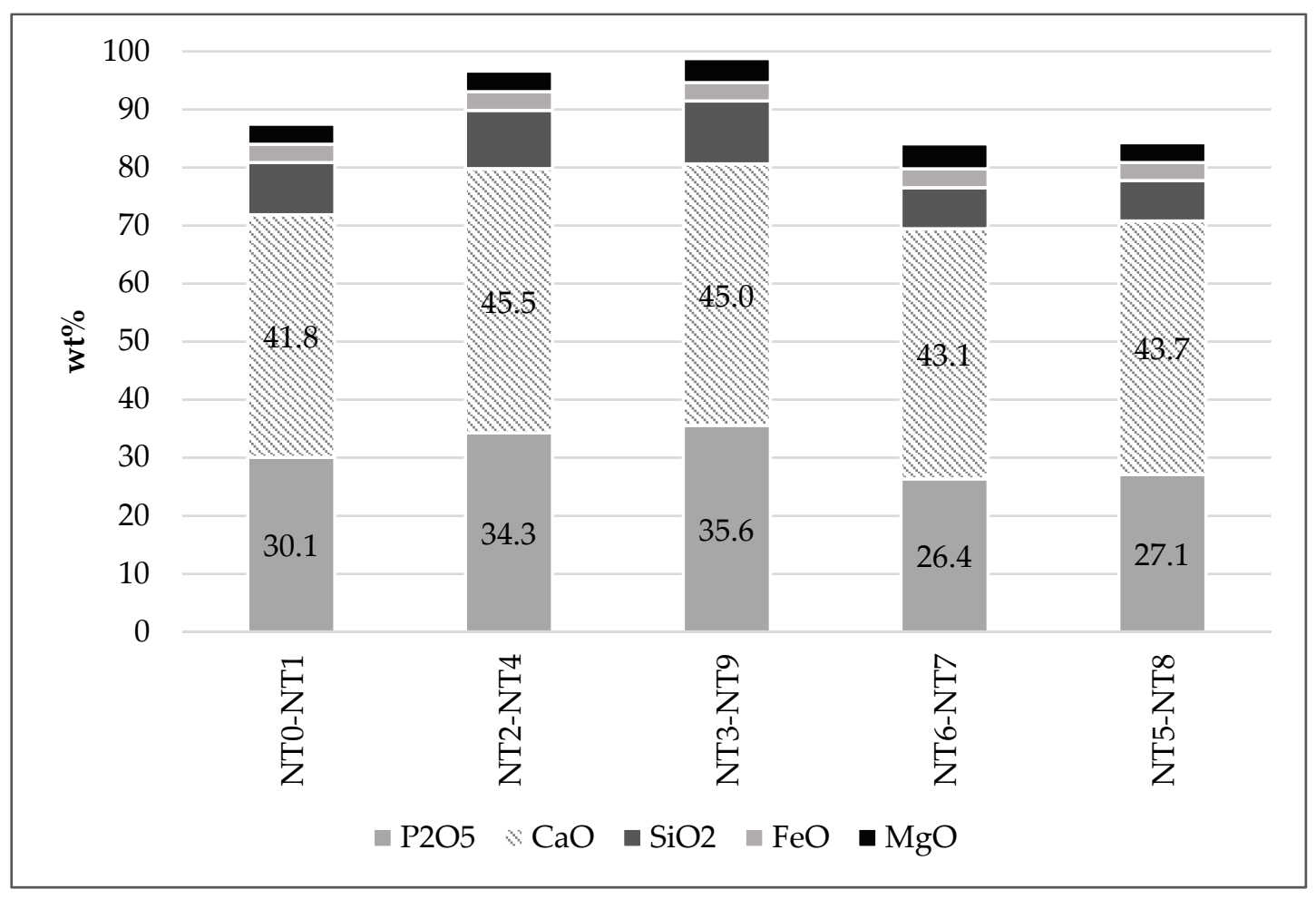

Figure 4. Slimes chemical composition for tests 1 (NT1) to 9 (NT9), wt\%. 
All the tailings from different flotation tests follow the same pattern in liberating the quartz and other impurities as the froth. In the tailings, an average of $70 \mathrm{wt} \%$ in each flotation round can be found in the particles larger than $45 \mu \mathrm{m}$ diameter. This number in fine particles $(-45 \mu \mathrm{m})$ is almost $10 \mathrm{wt} \%$. However, in the fine particle fractions there was still considerable amount of phosphate between 17.9 to $33.49 \mathrm{wt} \%$, which can be added to the final product to improve the recovery rate and grade. Although it is notable that the liberation of $\mathrm{Fe}_{2} \mathrm{O}_{3}$ occurs mainly in the fine particles, adding them to the final product does not impact the content of the $\mathrm{Fe}_{2} \mathrm{O}_{3}$ and it remained below the commercial requirements.

In test 7 , the content of the phosphate in the fourth flotation (RC4) in the fine particles is $35.79 \mathrm{wt} \%$. There is also considerable amount of phosphate (almost $10 \mathrm{wt} \%$ on average) in the coarser particles. This can be an indicator that continuing the experiment with $800 \mathrm{~g} / \mathrm{t}$ of collector dosage for more than $6 \mathrm{~min}$ can result in the flotation of apatite-bearing particles too.

However, as it was predicted, the main component in the concentrates was apatite, which was successfully depressed in the beneficiation process (Figure 6). The analysis of each fraction indicates the same pattern in phosphate content with the average of $34 \mathrm{wt} \%$ in fine particles and 25.048 in coarse particles. However, this number in tests 8 and 9 is almost equal in all the three fractions. The reason can be explained by the higher dosage of the collector and allocating adequate amount of time to the process to develop.

In addition, it could be observed (from Figures 5a-d and 6) that the content of the $\mathrm{CaO}$ is almost stable in the all the flotation products presenting dominantly in fine particles and to a lesser extent in coarse particles. However, in concentrates the content of the $\mathrm{CaO}$ is approximately $50 \%$ of the product. The separation of the $\mathrm{CaO}$ is usually associated with the separation of $\mathrm{MgO}$ (as dolomite) which is harmful to the fertilizer production. Although the content of the $\mathrm{MgO}$ was remarkably low (below $0.30 \mathrm{wt} \%$ on average), from the $\mathrm{CaO}$ content, it can be perceived that the higher the amount of the $\mathrm{CaO}$, the higher the $\mathrm{MgO}$ content. $\mathrm{CO}_{2}$ and $\mathrm{S}$ contents were significantly low, with an average of $2.18 \mathrm{wt} \%$ and $0.15 \mathrm{wt} \%$, respectively.

$\mathrm{Cd}$ content in random samples were measured which was less than $0.154 \mathrm{ppm}$ and in accordance with the unique characteristic of Estonian phosphorite (up to $5 \mathrm{ppm}$ ). The U content was also analyzed, and it was observed that the highest amount was $28 \mathrm{ppm}$.

\subsection{Mineralogy (XRD)}

The XRD (mineral composition) was done by the laboratory of the Geological Institute at Tallinn University of Technology and the result is presented in Table 3. To verify the results from previous analysis methods, tests NT5 and NT7 with 600 and $800 \mathrm{~g} / \mathrm{t}$ of collector dosage and 10 and 6 min of flotation time, respectively, were chosen for XRD analysis. As can be observed, in the flotation products, the amount of quartz is significantly higher with the maximum amount of $84.17 \%$ in NT5 Flo R-1 (the first segment collected foams from test 5) and $86.84 \%$ in NT7 Flo R-2 (the second segment collected foam from test 7) accompanied with almost $0.80-1.43 \%$ average amount of orthoclase in flotation products which is a secondary source of silicate. Whereas in concentrates the silicate content is the lowest comparing to the other products, with $7.93 \%$, and $12.17 \%$ for test 5 and 7 , respectively. Also, $\mathrm{XRD}$ results show that silicate content in the concentrate is composed of quartz mineral as the orthoclase was not identified in the concentrate mineral analysis. These results were in compliance with previous analysis which showed the same pattern in the separation process. 


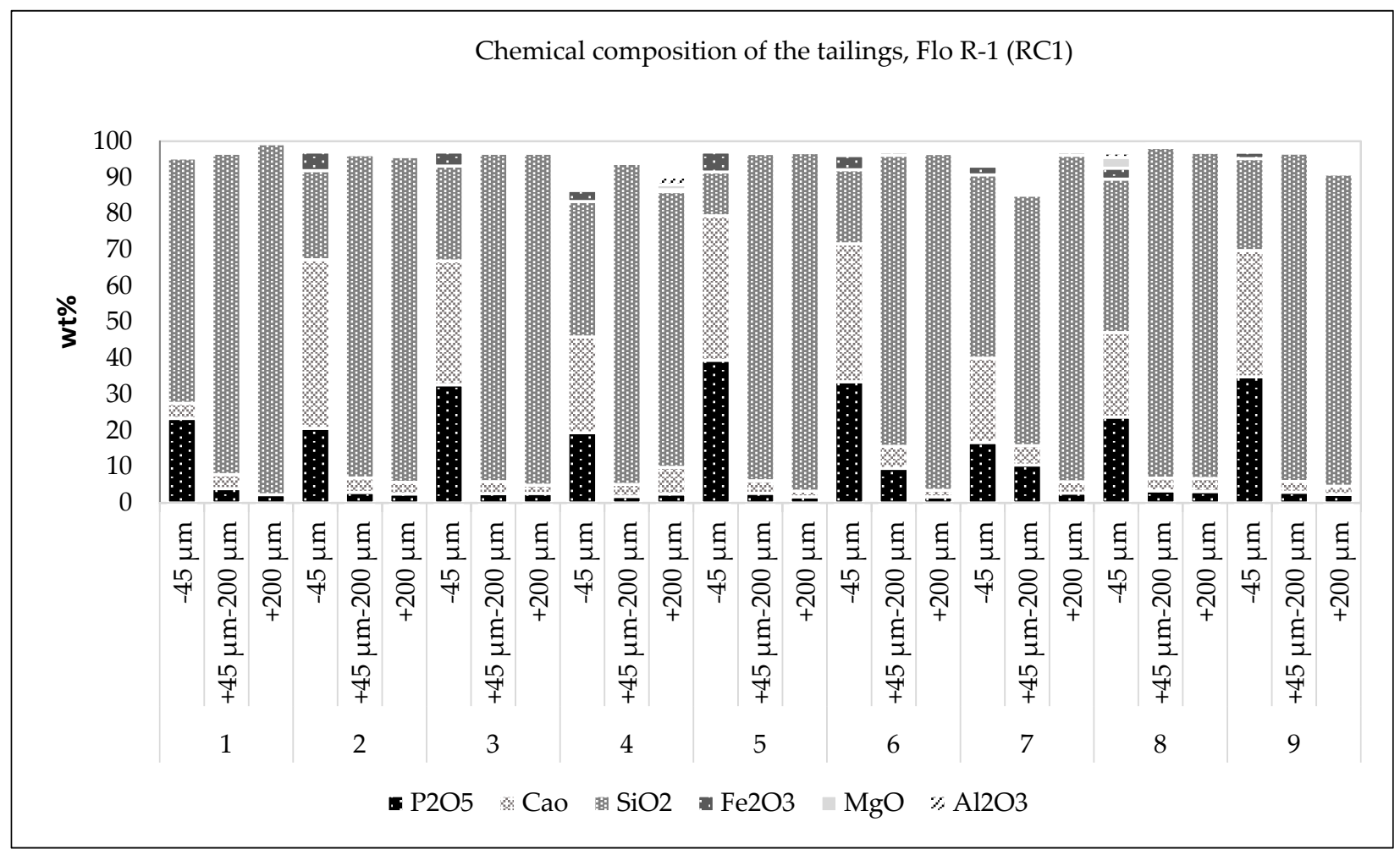

(a)

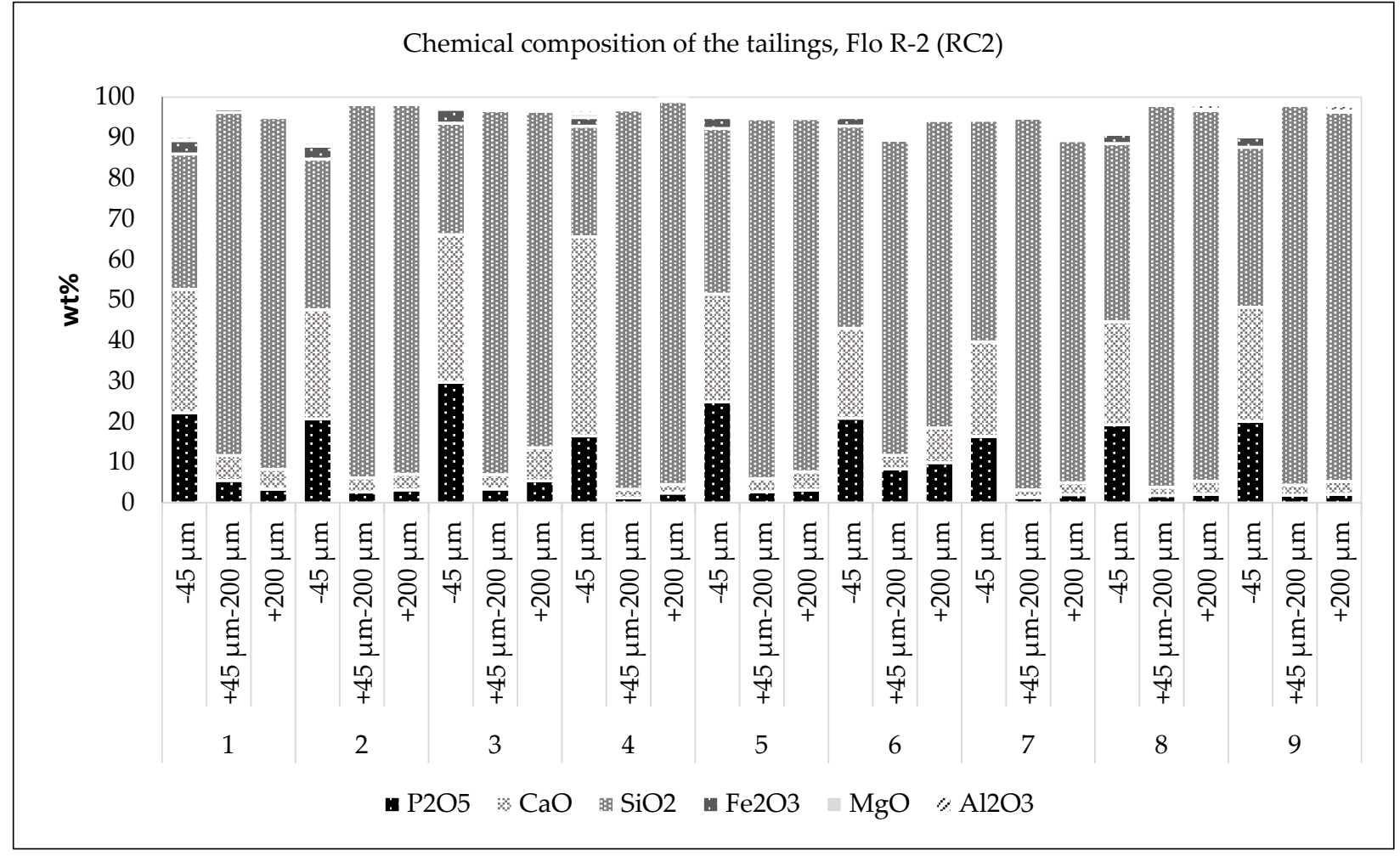

(b)

Figure 5. Cont. 


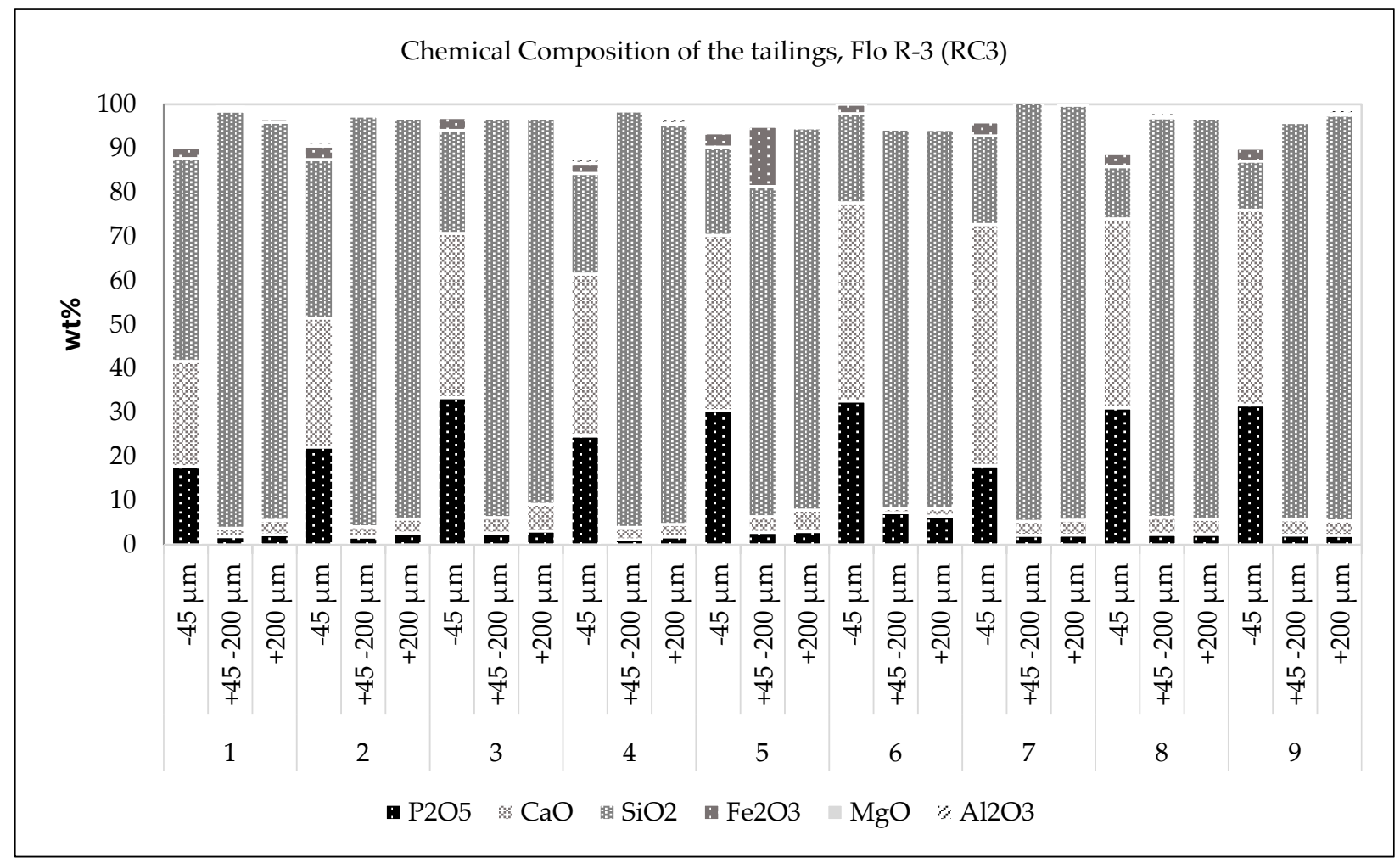

(c)

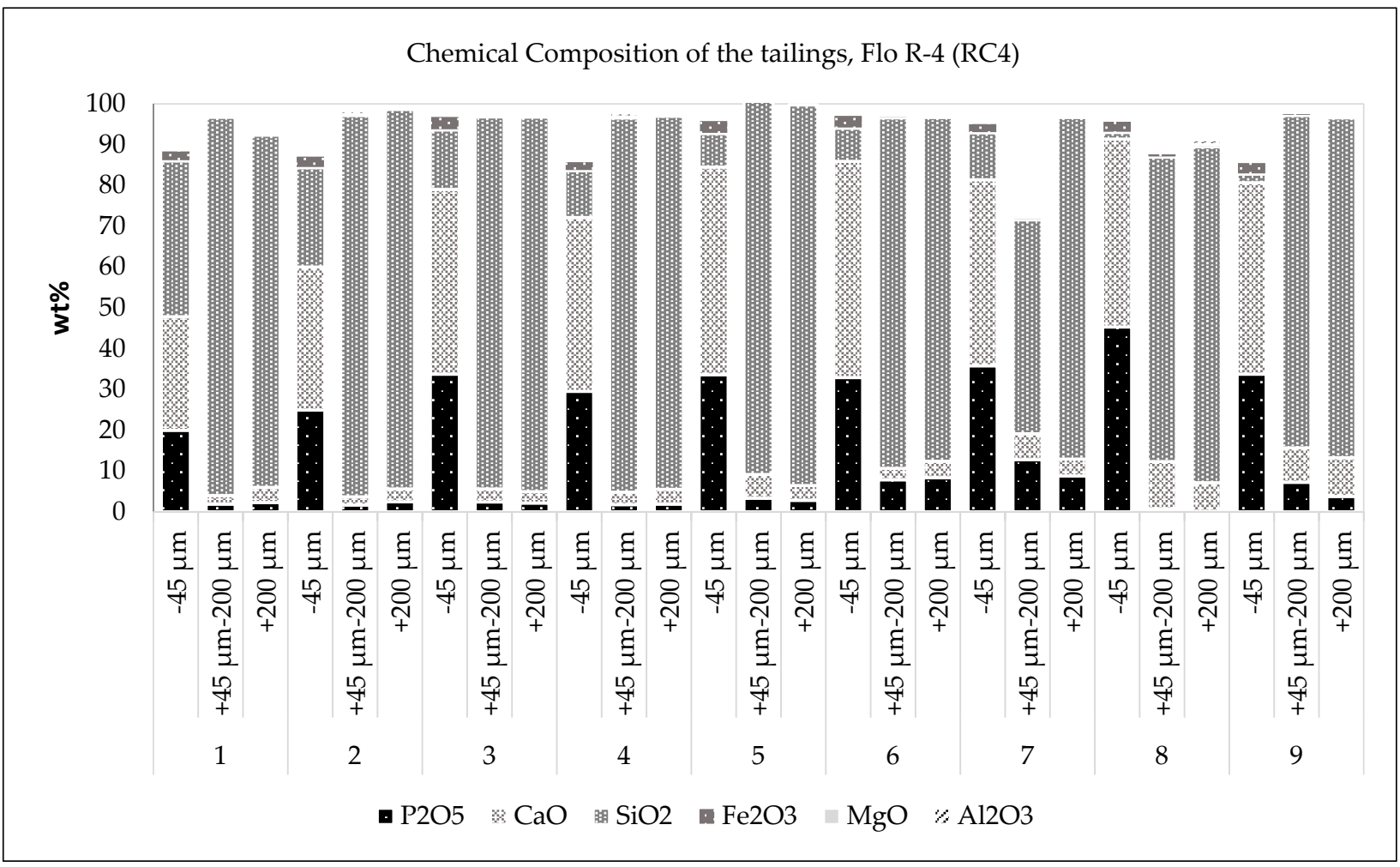

(d)

Figure 5. (a) Chemical composition of the tailings from the Flo R-1 (RC1) for tests 1 to 9. (b) Chemical composition of the tailings from the Flo R-2 (RC2) for tests 1 to 9. (c) Chemical composition of the tailings from the Flo R-3 (RC3) for tests 1 to 9. (d) Chemical composition of the tailings from the Flo R-4 (RC4) for tests 1 to 9. 


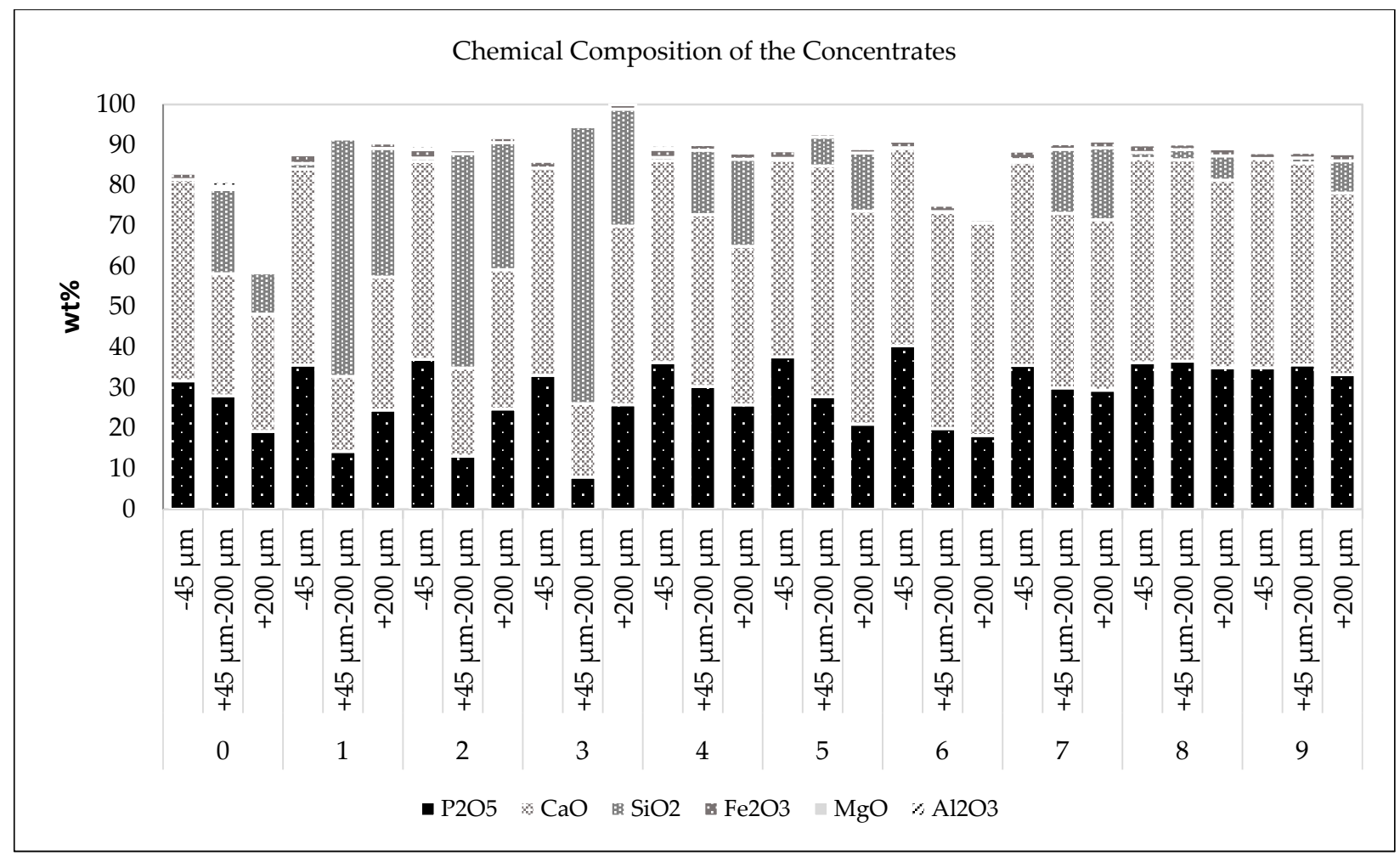

Figure 6. Chemical composition of the Concentrates for 10 conducted tests.

Table 3. Mineral analysis of the representative tests 5 and 7 (NT5, NT7).

\begin{tabular}{ccccc}
\hline Sample ID & Quartz & $\begin{array}{c}\text { Orthoclase } \\
\text { (K-Feldspar) }\end{array}$ & Apatite-(CaF) & Pyrite \\
\hline & \multicolumn{5}{c}{ Test5 } \\
\hline NT5-Flo R-1 & 84.17 & 1.03 & 14.00 & 0.80 \\
NT5-Flo R-2 & 83.12 & 0.94 & 15.54 & 0.39 \\
NT5-Flo R-3 & 72.17 & 1.35 & 26.14 & 0.34 \\
NT5-Flot R-4 & 64.57 & 1.43 & 33.62 & 0.38 \\
NT5-RT & 7.93 & N/A & 91.62 & 0.39 \\
& & Test7 & 23.27 & 0.98 \\
NT7-Flot R-1 & 74.58 & 1.05 & 11.82 & 0.24 \\
NT7-Flo R-2 & 86.84 & 0.88 & 26.05 & 0.26 \\
NT7-Flo R-3 & 72.27 & 1.31 & 26.12 & 0.20 \\
NT7-Flo R-4 & 72.18 & 1.17 & 87.12 & 0.41 \\
NT7-RT & 12.17 & N/A &
\end{tabular}

Being less than $1 \mathrm{wt} \%$ for both samples, pyrite $\left(\mathrm{FeS}_{2}\right)$ is the least existing mineral which makes the quality of the beneficiated ore higher due to adverse impacts of this mineral on fertilizer production.

\subsection{XRF}

XRF results revealed a considerable amount of REEs in the samples. The distribution of the REEs is almost similar in all the samples according to Figure 7 in that strontium content is the highest in concentrates and slimes with more than 3100 and 2700 ppm, respectively, followed by yttrium $(\mathrm{Y})$, cerium $(\mathrm{Ce})$, neodymium $(\mathrm{Nd})$, and lanthanum (La). Similarly, in flotation products, strontium (Sr) is of the highest amount with almost 1200 ppm. 


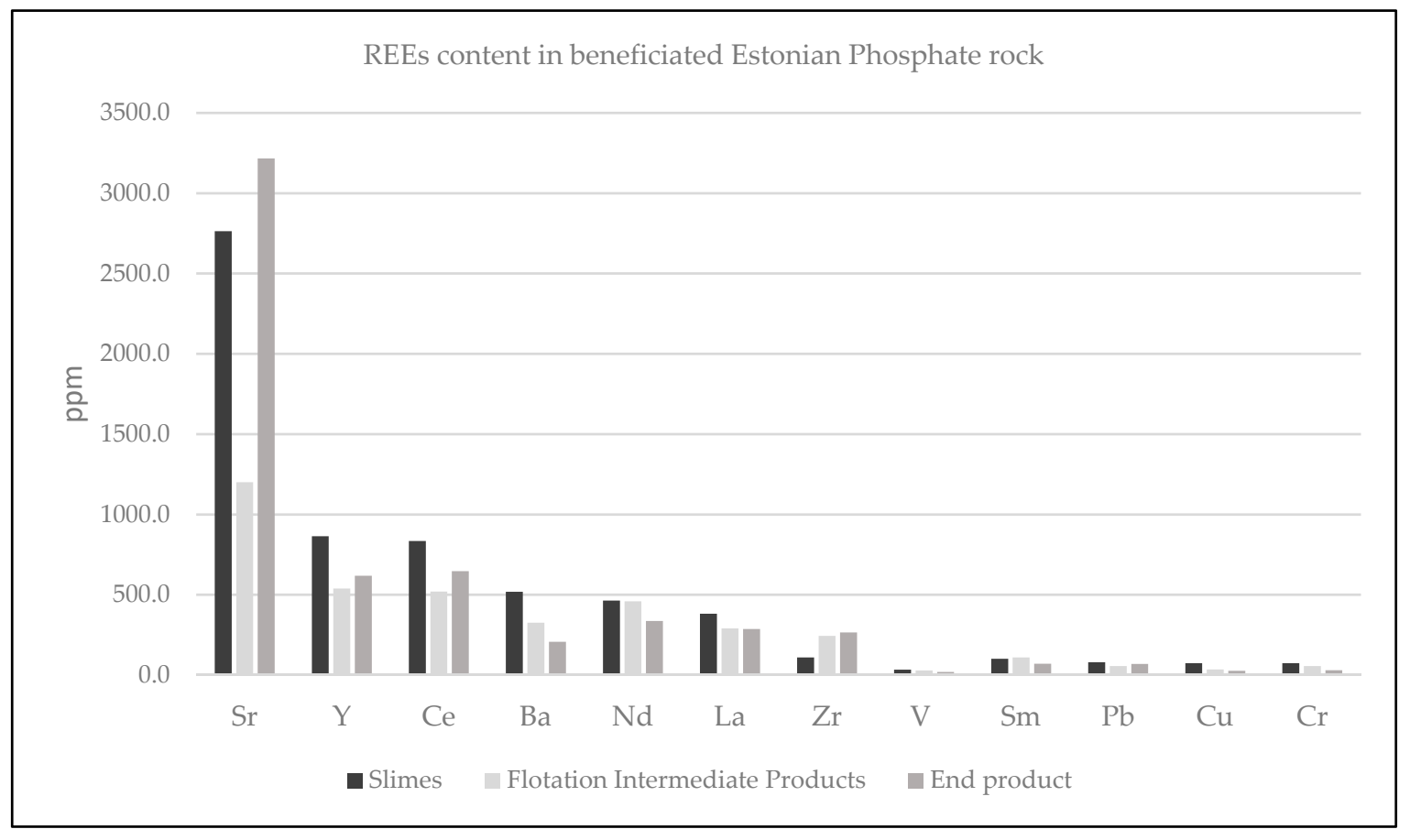

Figure 7. REEs content in beneficiated Estonian Phosphate rock.

From XRF analysis a quite comprehensive outlook can be seen showing Estonian phosphate rock as a valuable REEs source of which currently technological and economic values are well understood. This dataset provides a reliable source for further investigation of these elements extraction that is an ongoing research in Taltech Geological Institute (Tallinn, Estonia).

\subsection{Grades and Recovery Analysis}

In this section the recovery and grades of the Concentrates (CONC), the slimes added to the concentrates (CONC + slimes), and the fine particles of the tailings added to the slimes and the concentrates (CONC + slimes $+\mathrm{RC}-45 \mu \mathrm{m})$ are shown in the following diagrams. These illustrations provide an outlook to compare the various options that can represent the final product in the beneficiation of the Estonian phosphate rock.

According to Figure 8 , in limited time duration $(t=6 \mathrm{~min})$, adding more collector may increase the phosphate grade, from $21.4 \mathrm{wt} \%$ in test 1 to $30.12 \mathrm{wt} \%$ in test 7 . However, high amount of silica that remained in the concentrates decreases the quality of the final product due to the imposed difficulties in phosphoric acid production. By adding the collector dosage, although the $\mathrm{P}_{2} \mathrm{O}_{5}$ increase by almost 6-8 wt\%, yet the $\mathrm{SiO}_{2}$ content remained remarkably high. Thus, considering the collector price which is $€ 2200 /$ ton of the collector (according to GTK), increasing the collector dosage is neither cost-effective nor efficient. However, in a fast flotation process which energy consumption is critical, tests 4 and 7 still can be investigated, although the phosphoric acid production method should be taken into account because of the critical amount of $\mathrm{SiO}_{2}$ (Figure 8).

When the flotation process was conducted in $10 \mathrm{~min}$, lower dosage of the collector as it can be seen in test 2 did not deliver a high-quality concentrate (20.34 $\mathrm{wt} \%$ phosphate grade) because the content of the quartz was still high at $37.88 \mathrm{wt} \%$ (Figure 9). However, by adding the collector dosage, particles had more chances to adhere to the air-bubbles and ascend in the suspension. Consequently, the concentrates in tests 5 and 8 contained phosphate grade and recovery of almost $32.00 \mathrm{wt} \%$ and $91.05 \%$ and $35.56 \mathrm{wt} \%$ and $86.46 \%$, respectively. The quartz content reduced from $37.88 \mathrm{wt} \%$ in test 2 to $11.39 \mathrm{wt} \%$ in test 5 and $4.62 \mathrm{wt} \%$ in test 8 as the collector dosage increased from $400 \mathrm{~g} / \mathrm{t}$ to $800 \mathrm{~g} / \mathrm{t}$. 


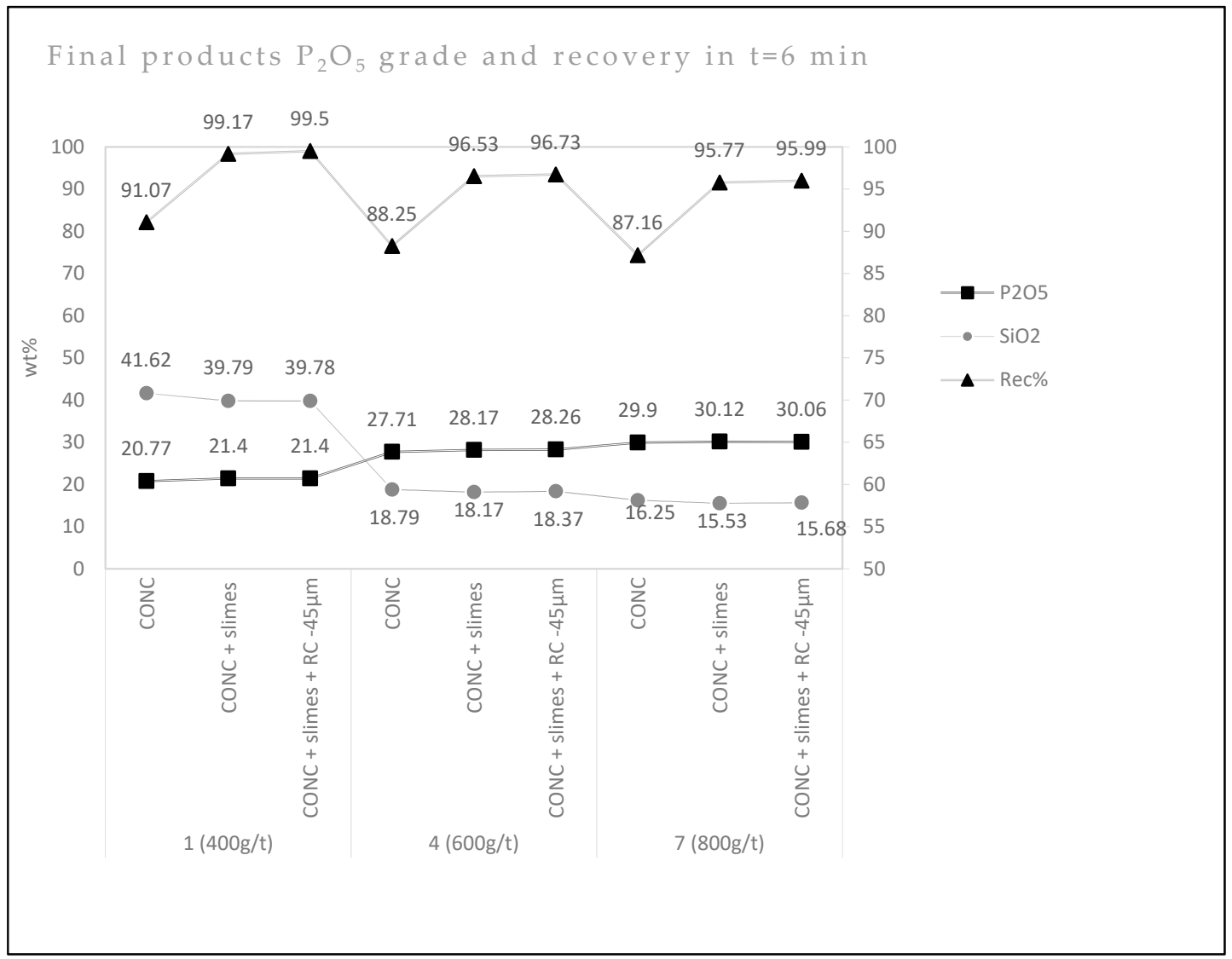

Figure 8. Grades and recovery changes in tests 1,4 , and 7 for the final product ( $t=6 \mathrm{~min})$.

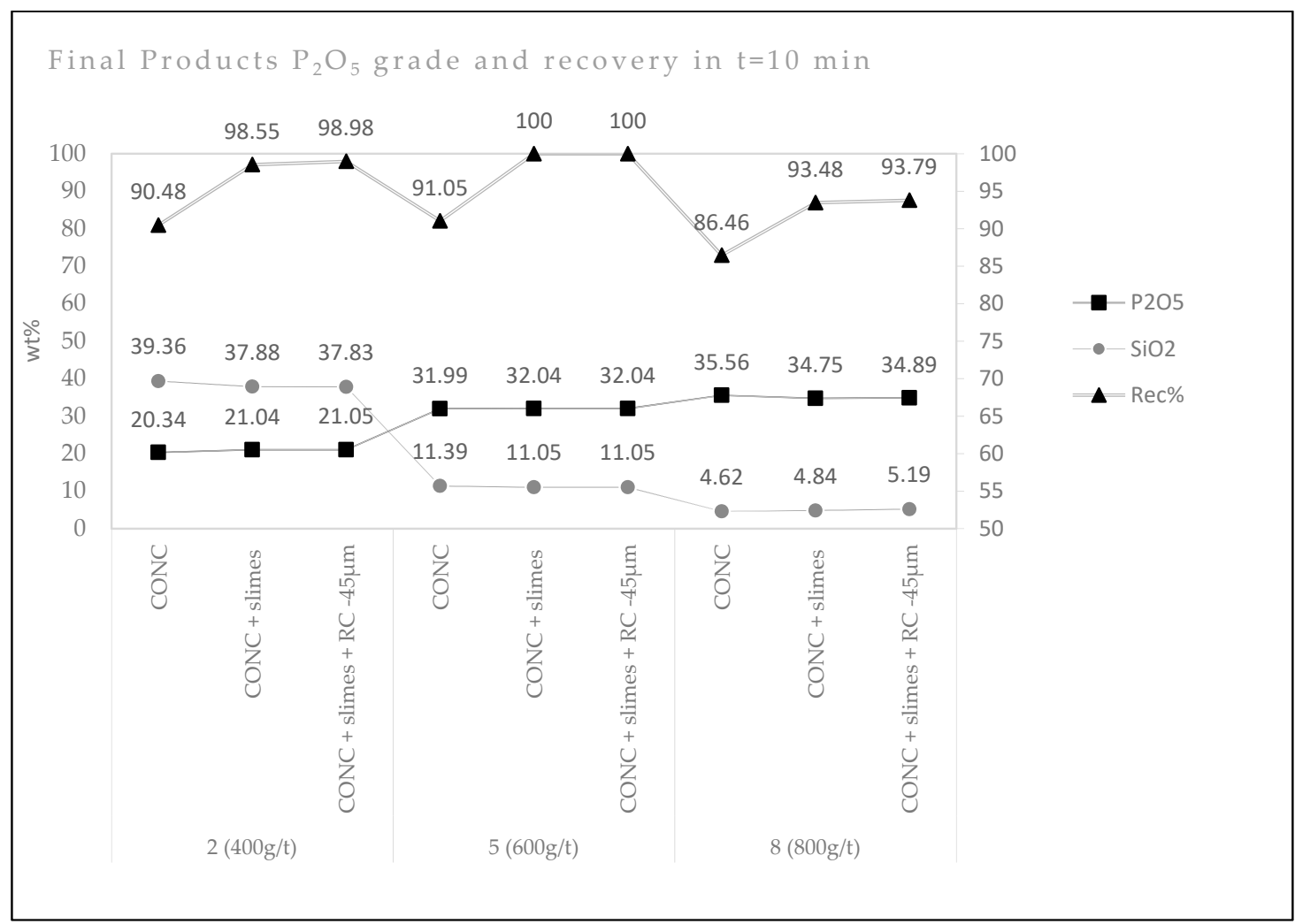

Figure 9. Grades and recovery changes in tests 2,5 , and 8 for the final product $(t=10 \mathrm{~min})$. 
Overall, tests 5 and 8 with 10 min flotation time with 600 and $800 \mathrm{~g} / \mathrm{t}$ of the reagent, respectively can be the optimum solution for beneficiation of the Estonian phosphate rock.

Allocation an extra time to the flotation process with a low dosage of the collector as in test 3 and 6 did not deliver a high-quality concentrate as it is represented in Figure 10. In test 9 , a high grade of phosphate and recovery rate with $32.13 \mathrm{wt} \%$ and $84.76 \%$ were obtained, respectively. This test delivered a high quality product and can be another optimum solution for the enrichment of the rock.

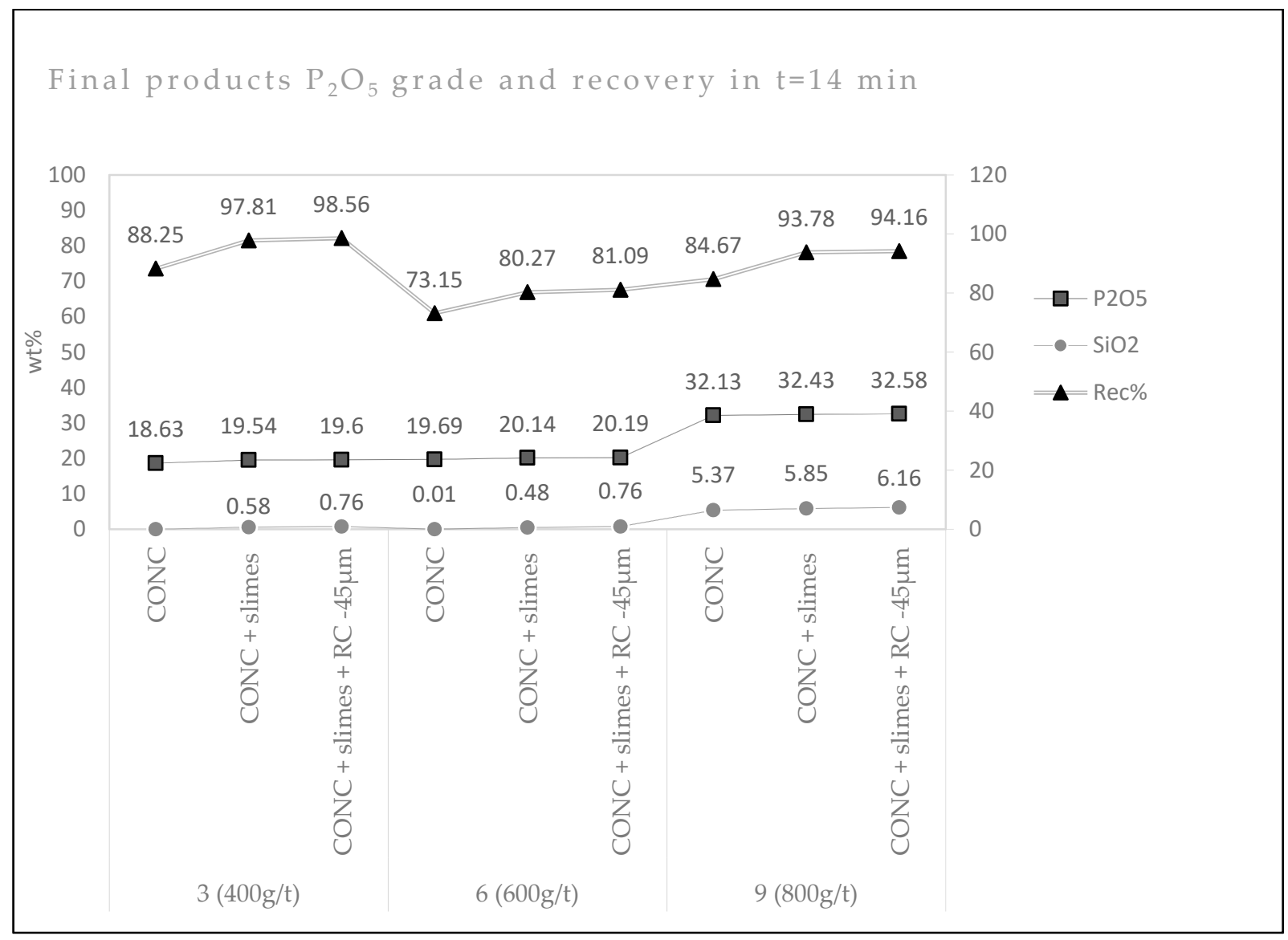

Figure 10. Grades and recovery changes in tests 3,6 , and 9 for the final product. $(t=14 \mathrm{~min})$.

The quartz content in all the tests remained steady after adding either the fine particles, slimes, or both, having no effect on the recovery and grade of the phosphate. This is due to the optimum grinding time before flotation process. As the effect of quartz on the phosphoric acid production highly depends on the utilized technology, the optimum amount can be identified in industrial scale.

Overall, this analysis shows that before adding the slimes and fine particles of tailings, the concentrates have a high quality and industrial level of chemical components in tests 5 , 8, and 9. Therefore, they can represent the most efficient system for Estonian phosphate rock enrichment. With more than $31 \mathrm{wt} \%$ phosphate, they can be used for phosphoric acid production.

It was discussed that tests 5,8 , and 9 were chosen for further investigation due to the above-mentioned analysis of the obtained results. Table 4 summarizes the recovery rate and chemical characteristics of the three chosen tests. Despite of having $100 \%$ recovery and $32.04 \mathrm{wt} \% \mathrm{P}_{2} \mathrm{O}_{5}$ grade in test 5 , the content of the iron (III) oxide $\left(\mathrm{Fe}_{2} \mathrm{O}_{3}\right)$ is $2 \mathrm{wt} \%$ on the threshold and the highest among the selected tests. Since the fertilizer composition mainly depends on the soil type, each of these products can be suitable for specific type of soil. 
Table 4. Summary of the achieved results for the three selected optimum tests (Tests 5, 8, and 9).

\begin{tabular}{|c|c|c|c|c|c|c|c|c|}
\hline & \multicolumn{2}{|c|}{$\mathrm{P}_{2} \mathrm{O}_{5} \%$} & \multicolumn{6}{|c|}{ Elemental Composition (\%) } \\
\hline & Grade & Recovery & $\mathrm{CaO}$ & $\mathrm{SiO}_{2}$ & $\mathrm{Fe}_{2} \mathrm{O}_{3}$ & $\mathrm{MgO}$ & $\mathrm{Al}_{2} \mathrm{O}_{3}$ & $\mathrm{CaO} / \mathrm{P}_{2} \mathrm{O}_{5}$ \\
\hline Recommended wt $\%$ : & & & & & $<2-3$ & $<1$ & $<1$ & $<1.6$ \\
\hline \multicolumn{9}{|c|}{ TEST 5} \\
\hline CONC & 31.99 & 91.05 & 44.91 & 11.39 & 1.78 & 0.38 & 0.17 & 1.4 \\
\hline CONC + slimes & 32.04 & 100 & 44.85 & 11.05 & 2 & 0.38 & 0.22 & 1.4 \\
\hline CONC + slimes + RC $-45 \mu \mathrm{m}$ & 32.04 & 100 & 44.85 & 11.05 & 2 & 0.38 & 0.22 & 1.4 \\
\hline \multicolumn{9}{|c|}{ TEST 8} \\
\hline CONC & 35.56 & 86.46 & 47.65 & 4.62 & 1.65 & 0.28 & 0.13 & 1.34 \\
\hline CONC + slimes & 34.75 & 93.48 & 47.26 & 4.84 & 1.79 & 0.25 & 0.19 & 1.36 \\
\hline CONC + slimes + RC $-45 \mu \mathrm{m}$ & 34.89 & 93.79 & 47.43 & 5.19 & 1.82 & 0.25 & 0.2 & 1.36 \\
\hline \multicolumn{9}{|c|}{ TEST 9} \\
\hline CONC & 32.13 & 84.67 & 43.87 & 5.37 & 1.53 & 0.22 & 0.49 & 1.37 \\
\hline CONC + slimes & 32.43 & 93.78 & 43.97 & 5.85 & 1.67 & 0.2 & 0.45 & 1.36 \\
\hline CONC + slimes + RC $-45 \mu \mathrm{m}$ & 32.58 & 94.16 & 44.18 & 6.16 & 1.7 & 0.2 & 0.45 & 1.36 \\
\hline
\end{tabular}

In test 8 , an improvement in the grade by $7 \%$ can be seen after adding the slimes and fine particles of the tailings. Nevertheless, it resulted in increasing the grade of quartz by 0.57 and the iron (III) oxide by 0.17 . Yet the final product of test 8 still contained the highest phosphate grade and recovery rate among all the tests with around $35 \mathrm{wt} \%$ and $94 \%$, orderly. Similarly, test 9 shows an increase in the recovery rate, grade, silicate and $\mathrm{Fe}_{2} \mathrm{O}_{3}$ content. Therefore, slimes and fine particles of tailings can be recycled for REEs extraction and other industrial applications since they are not significantly improve the chemical components of the final product for fertilizer production.

The ratio of $\mathrm{CaO} / \mathrm{P}_{2} \mathrm{O}_{5}$ is in the required level in all the tests and shows a steady ratio with an average of 1.37 .

\section{Conclusions}

Estonia with more than 700 million tons of phosphate rock is the largest unused phosphate deposit in European Union. Estonian phosphorite is a unique, shelly, siliceous sedimentary rock with a significantly low amount of $\mathrm{Cd}$ (up to $5 \mathrm{ppm}$ ) and $\mathrm{U}$ (up to $50 \mathrm{ppm}$ ), while numerous valuable minerals such as REEs can be obtained by enrichment of the mineral. Despite of all the potential technological and economic advancements, Estonian phosphorite is not exploited. This paper is an analysis on the conducted flotation processes in various time and collectors dosage to obtain the optimum beneficiation system parameters for this mineral. Thus, the tailings, slimes, and the concentrates of the 10 designed experiments were analyzed by screening, particle size distribution analysis, $\mathrm{XRF}$, chemical assays, and XRD.

From the above-mentioned analytical methods, it was observed that after screening and particle size distribution measurement of the samples, majority of the floated particles are between 45 and $200 \mu \mathrm{m}$ with the average mean size of $165.5 \mu \mathrm{m}$, while in concentrates most of the particles size belongs to coarse-grain fraction with more than $200 \mu \mathrm{m}$ with the average mean size of $436.93 \mu \mathrm{m}$. These data can be used in pre-processing of the rock before the flotation to obtain the most efficient particle size in the feedstock.

The XRF, XRD, and chemical analysis showed that quartz content in the flotation products was higher while in concentrates, slimes, and fine particles of the tailings $\mathrm{P}_{2} \mathrm{O}_{5}$ content was the dominant element.

At limited time $(6 \mathrm{~min})$ increasing the collector dosage produced a relatively highgrade concentrate although the quartz content was also the highest. By maintaining the flotation time in $10 \mathrm{~min}$ and increasing the collector dosage, the highest quality of the concentrates was obtained. According to $14 \mathrm{~min}$ of flotation time, only with a higher dosage of the collector was an acceptable result achieved. 
It was observed that the flotation time is a critical factor combined with collector dosage in the flotation process. This is because it provides a solid-gas-liquid phase interaction to reach to the optimum energy level and ascend from the slurry to the surface. Longer duration of the process led to a higher volume of generated froth and higher rate of attachment of the hydrophobic particles to the air bubbles surface. Also, a higher dosage of the collector resulted in a higher froth volume and easier separation. With the same dosage of the collector, the extended flotation time resulted in more quartz content in the concentrates and more phosphate content in the tailings (tests 7-9).

The growing demand for the fertilizers leads to exploiting new phosphate deposits. This study offers an overview of the Estonian phosphate rock beneficiation and further studies on the mathematical modeling of the rock. In addition, the presented data can be utilized for further studies in recycling the tailings and extraction of REEs.

Author Contributions: Conceptualization, K.T. (Kadriann Tamm), J.Y. and K.T. (Kaia Tõnsuaadu); Data curation, J.Y.; Formal analysis, Z.A.Z.; Funding acquisition, A.T.; Investigation, K.T. (Kaia Tõnsuaadu); Methodology, K.T. (Kadriann Tamm), R.K. and J.K.; Project administration, K.T. (Kadriann Tamm); Resources, J.Y. and K.T. (Kaia Tõnsuaadu); Supervision, R.K., J.K. and J.Y.; Visualization, Z.A.Z.; Writing—original draft, Z.A.Z.; Writing—review \& editing, K.T. (Kadriann Tamm). All authors have read and agreed to the published version of the manuscript.

Funding: This research was funded by the Estonian Research Council grant (PUTJD705, IUT33-19), by the Estonian Ministry of Education (Research grant RITA1/01-01-11) and the Geological Survey of Estonia "The APC was funded by Taltech".

Acknowledgments: This work was financially supported by the Estonian Research Council grant (PUTJD705, IUT33-19), by the Estonian Ministry of Education (Research grant RITA1/01-01-11) and the Geological Survey of Estonia, which are gratefully acknowledged. Also, the authors express their gratitude to Geological Institute in Tallinn University of Technology for contribution.

Conflicts of Interest: The authors declare no conflict of interest.

\author{
Abbreviations \\ PR Phosphate Rock \\ Taltech Tallinn University of Technology \\ GI Geological Institute of Tallinn University of Technology \\ GSE Geological Survey of Estonia
}

\title{
References
}

1. Puura, I.; Nemliher, J. Advances in Skeletal Apatite Mineralogy. Folia Baeriana 1999, 7, 64-69.

2. Puura, V. (Ed.) Geology and Mineral Resources of the Rakvere Phosphorite-Bearing Area, Tallinn; Valgus Publishers: Tallinn, Estonia, 1987.

3. Kawatra, S.K.; Carlson, J.T. Beneficiation of Phosphate Ore; Society for Mining, Metallurgy and Exploration: Littleton, CO, USA, 2014; ISBN 978-0-87335-391-5.

4. Ilyin, A.V.; Heinsalu, H.N. Early Ordovician shelly phosphorites of the Baltic Phosphate Basin. In Phosphorite Research and Development; Notholt, A.J.G., Jarvis, I., Eds.; Geological Society, London, Special Publication: London, UK, 1990; Volume 52, pp. 253-259.

5. Bauert, H.; Soesoo, A.; Hade, S. Strategic raw materials in Estonia, Conference Paper; Department of Geology, University of Tartu: Tartu, Estonia, 2015; Volume 2015, pp. 16-17.

6. Raukas, A.; Teedumäe, A. (Eds.) Geology and Mineral Resources of Estonia; Estonian Academy Publishers: Tallinn, Estonia, 1997; p. 436. ISBN 9985-50-185-3.

7. Vind, J. Review of the Exploration Potential of the Estonian Black Shale (Graptolitic Argillite) Deposit; Geological Survey of Estonia: Rakvere, Estonia, 2018.

8. Baturin, G.N.; Ilyin, A.V. Comparative Geochemistry of Shell Phosphorites and Dictyonema Shales of the Baltic. Geochem. Int. 2020, 51, 23-32.

9. Altschuler, Z.S. The Geochemistry of Trace Elements in Marine Phosphorites. Part I. Characteristic Abundances and Enrichment; Bentor, Y.K., Ed.; Marine phosphorites, Special Publications: London, UK, 1980.

10. Aydin, I.; Aydin, F.; Saydut, A.; Bakirdere, E.G.; Hamamci, C. Hazardous metal geochemistry of sedimentary phosphate rock used for fertilizer. Microchem. J. 2010, 96, 247-251. [CrossRef] 
11. Roselli, C.; Desideri, D.; Meli, M.A. Radiological characterization of phosphate fertilizers: Comparison between alpha and gamma spectrometry. Microchem. J. 2009, 91, 181-186. [CrossRef]

12. Tulsidas, H.; Gabriel, S.; Kiegiel, K.; Haneklaus, N. Uranium resources in EUphosphate rock imports. Resour. Policy 2019, 61, 151-156. [CrossRef]

13. Negm, A.A.; Abouzeid, A.-Z.M. Utilization of solid wastes from phosphate processing plants. Physicochem. Probl. Miner. Process. 2008, 42, 5-16.

14. El-Gillani, D.A.; Abouzeid, A.-Z.M. Flotation of carbonates from phosphate ores in acidic media. Int. J. Miner. Process. 1993, 38, 235-256. [CrossRef]

15. Rodrigues, A.J.; Brandao, P.R.G. The influence of crystal chemistry properties on the floatability of apatites with sodium oleate. Miner. Eng. 1993, 6, 643-653. [CrossRef]

16. Santana, R.C.; Duarte, C.R.; Ataide, C.H.; Barrozo, M.A.S. Flotation selectivity of phosphate ore: Effect of particle size and reagent concentration. Sep. Sci. Technol. 2011, 46, 1511-1518. [CrossRef]

17. Santana, R.C.; Farnese, A.C.C.; Fortes, M.C.B.; Ataide, C.H.; Barrozo, M.A.S. Influence of particle size and reagent dosage on the performance of apatite flotation. Sep. Sci. Technol. 2008, 64, 8-15. [CrossRef]

18. Qun, W.; Heiskanen, K. Batch flotation tests by fatty acid on a phosphate-iron oxide-silicate regolith ore sample from Sokli, Finland. Miner. Eng. 1990, 3, 473-481. [CrossRef]

19. Silva, J.P.P.; Baltar, C.A.M.; Gonzaga, R.S.G.; Peres, A.E.C.; Leite, J.Y.P. Identification of sodium silicate species used as flotation depressants. Min. Met. Process. 2012, 29, 207-210. [CrossRef]

20. Rao, D.S.; Vijayakumar, T.V.; Angadi, S.; Prabhakar, S.; Raju, G.B. Effects of modulus and dosage of sodium silicate on limestone flotation. MAEJO Int. J. Sci. Technol. 2014, 4, 397-404.

21. Guimarães, R.C.; Araujo, A.C.; Peres, A.E.C. Reagents in igneous phosphate ores flotation. Min. Eng. 2005, 18, 199-204. [CrossRef]

22. Ruan, Y.; Zhang, Z.; Luo, H.; Xiao, C.; Zhou, F.; Chi, R. Effects of metal ions on the flotation of apatite, dolomite and quartz. Minerals 2018, 8, 141. [CrossRef]

23. Teague, A.J.; Lollback, M.C. The beneficiation of ultrafine phosphate. Min. Eng. 2012, 27, 52-59. [CrossRef]

24. Luo, H.; Liu, L.; Xie, B.; Ou, S. Effect of $\mathrm{Ca}^{2+}, \mathrm{Mg}^{2+}, \mathrm{PO}_{4}{ }^{3-}$, and $\mathrm{SO}_{4}{ }^{2-}$ on the Flotation of Phosphate. In Beneficiation of Phosphates: New Thought, New Technology, New Development; Zhang, P., Miller, J., El-Shall, H., Eds.; SME: Denver, CO, USA, $2012 ;$ pp. 33-38.

25. Parker, T.; Wang, G. Solving Global Phosphate Challenges; ArrMaz: Mulberry, FL, USA, 2018; Available online: https://arrmaz.com/ wp-content/uploads/2018/03/ArrMaz_Solving_Global_Phosphate_Challenges_World_Fertilizer_March2018.pdf (accessed on 8 January 2021). 